\title{
IS CHRISTELIKE WETENSKAP MOONTLIK?
}

\author{
PROF. DR. P. S. DREYER
}

\section{A. INLEIDING:}

Wanneer 'n mens oor Christelike Wetenskap redeneer staan jy heel aan die begin reeds voor 'n probleem naamlik op watter punt begin die redenasie? Voorstanders van Christelike Wetenskap begin (sover ek hulle ken) altyd by die Christelike geloof of die Skrif of die Christelike lewensopvatting en wêreldbeskouing of liefs by aldrie, en beweeg daarvandaan na die Wetenskap toe. Hierdie metode hou in dat in die eerste plek implisiet of eksplisiet gestel word dat die Christengelowige altyd by die Skrif moet begin, omdat die Skrif as die Woord van God die voorrang bo alle ander sake moet geniet. In die tweede plek hou dit in wat 'n norm apriories (dit wil sê voorafgaande aan en onafhanklik van die verskynsel wat bestudeer word) ontwerp word waarna dan die wetenskap as bestudeerde fenomen benader word. Vanuit die Skrif en Calvyn word byvoorbeeld die soli deo gloria as norm, dit wil sê as meetsnoer en rigsnoer, gestel en die wetenskap daarvolgens beoordeel.

Nou klink dit baie mooi. Daar sit 'n stuk ad hominem appél in: Ons is almal gelowige Christene en dit klink vir ons reg om so te redeneer. Die man wat nie so redeneer nie, staan onder verdenking en moet homself verdedig.

Maar al klink dit nou ook hoe mooi, is dit nie noodwendig reg nie. Die saak wat ons bestudeer, ons studie-objek, is die wetenskap. Ons gee voor dat ons self wetenskaplik gevormde en belangstellende mense is. Die antwoorde wat ons op ons vrae vind, moet wetenskaplik verantwoord wees, anders sal dit ons onbevredig laat. As ons nie die saak wetenskaplik benader nie, gaan ons met geloof teen geloof, lewensopvatting teen lewensopvatting, diepste oortuiging teenoor diepste oortuiging stel en ons gaan nêrens uitkom nie, behalwe dat ons moet bely ons verskil van mekaar of dat ons moontlik dieselfde geloofsoortuigings huldig - maar die saak waaroor dit gaan, het ons nog nie bereik nie.

Nou is dit so dat iedereen met 'n wetenskaplike vorming weet dat daar net een wetenskaplik aanvaarbare metode van werk is, en dit is om te begin om jou te vergewis van die feite aangaande jou studie-objek-. (Hierop kom ek later weer terug - hier stel ek dit net). Wie die feite misken, bou op sand. 
As taal en die gebruik daarvan enige betekenis het, is die objek waarmee ons te doen het wetenskap, maar dan wetenskap wat op 'n bepaalde wyse gekwalifiseer is, naamlik Christelike wetenskap. Ons probleem is of hierdie kwalifikasie in die verband waarin dit staan, enige betekenis het. Die eerste tema wat ek dus te berde bring, is wetenskap.

\section{B. WETENSKAP:}

Wetenskap is 'n min of meer omvangryke, gesistematiseerde corpus van die kennis, maar dan kennis wat aan bepaalde vereistes beantwoord:

1. Kennis is altyd kennis aangaande iets. Ons weet nie net nie, ons weet iets. Dit is die inhoudelike aspek van kennis en dit bestaan uit die feitelike gegewens van ons objek van studie.

2. Voordat hierdie kennis as wetenskaplike kennis kan geld, moet hierdie kennis:

2.1. Metodies verky wees. Metode is die belangrikste faktor in wetenskaplike werk en dit sluit in werklikheid al die vereistes in wat ons hieronder terwille van die duidelikheid stel. Daar is talle metodes en geen metode kan as sodanig aanspraak maak op absoluutheid of selfs op voorrang nie. Die toets vir 'n metode is of dit doeltreffend is, dit wil sê, of dit ons in staat stel om die bepaalde studie-objek te ken soos dit is en soos ons dit wil ken. Die hoofmomente van wetenskaplike metode is:

2.1.1. Stofversameling. Ons probeer soveel moontlik feitelike gegewens aangaande ons studie-objek versamel.

2.1.2. Probleemformulering. Enige leemte (bv. ontbrekende gegewens, logiese teensprake, onverklaarbare verbande, ens) in ons kennis is 'n probleem. Ons moet dit so noukeurig moontlik afgrens en rigting aan ons ondersoek gee.

2.1.3. Hipotesevorming. ' $n$ Hipotese is die formulering van 'n vermoede gegrond op reeds bevestigde kennis en op die analogie van bekende prosedures dat die oplossing van die probleem in 'n bepaalde rigting gesoek moet word.

2.1.4. Verfikasie. Met die tegnieke tot beskikking van die wetenskaplike probeer hy vasstel of die hipotese korrek is. As dit korrek is, is dit nie meer hipotese nie, maar deel van ons bevestigde kennis. As dit nie korrek is nie, begin ons weer van vooraf aan.

2.2. Gefundeerd wees. In die verband van die wetenskap is die fundering altyd immanent, byvoorbeeld in noukeurige waarneming of logiese steekhoudenheid. Die wetenskaplike relevansie van transendente fundering kom later te berde. 
2.3. Objektief wees, waarmee ons nie bedoel dat die kennende subjek, in casu die wetenskaplike, geen rol speel nie. Onder die objektiwiteit van ons kennis bedoel ons dat dit die strewe is om die studie-objek te ken soos dit is, en nie soos ons hom graag wil hê of soos ons dink hy behoort te wees nie.

2.4. Verifieerbaar wees. Dit beteken dat enigiemand met die nodige bekwaamheid moet kan toets en kontroleer of die kennis waar en korrek is.

2.5. Mededeelbaar wees, met ander woorde dit moet redelik verstaanbaar aan medewetenskaplikes meegedeel kan word.

Laat ons dit weer eens duidelik stel: in die wetenskap gaan dit om kennis aangaande 'n bepaalde studie-objek. Die doel van al hierdie eise is om ons kennis steeds meer en meer uit te brei, presieser te mak en sekerder te maak. By al hierdie eise is daar ook sekere vooronderstellings waarvandaan ons uitgaan, hoewel dit meesal as vanselfsprekend geïmpliseer word en nie eksplisiet gestel word nie. Sulke wetenskaplike vooronderstellings is byvoorbeeld dat daar 'n samehang en reëlmaat in die ervaringswerklikheid bestaan, dat natuurprosesse geen diskontinuiteit toelaat nie en so meer. Hierdie vooronderstellings is apriories, dit wil sê dit word nie uit die studie van ons studie-objek verky nie, maar gaan daaraan vooraf en word deur die studie veronderstel. Dit is egter almal immanente vooronderstellings in die sin dat dit deur die mens gestel word om sy wetenskaplike werk moontlik te mak en dat dit deur die wetenskaplike aktiwiteit self bevestig word.

Uit bostaande is dit duidelik dat wetenskap - alle wetenskap, ook die teologie - 'n geheel en al menslike aangeleentheid is. Wetenskaplike kennis is daarom altyd relatief, omdat die mens gebrekkig en ten dele ken. Wetenskaplike uitsprake is daarom nooit absoluut nie, maar hipoteties of voorwaardelik en voorlopig van aard, dit wil sê, die wetenskaplike uitspraak veronderstel altyd dat jy daarby sê: sover ons kennis nou strek en op voorwaarde dat daardie kennis waar is, kan ek A.B.C. beweer en kan ek die bewering as waar bedoel, maar dit is 'n waarheid wat alleen sal geld tot tyd en wyl ons meerdere feitelike kennis en dieper insig verkry het.

\section{DIE TERM CHRISTELIK:}

Die term Christelik beteken behorende by of voortspruitende uit die Christelike geloof. Die Christelike geloof word in die hart van die mens deur die Heilige Gees gewek as antwoord op die aanspreek deur die Woord van God. Die inhoud van ons geloof, dit wil sê, wat ons glo,, ontvang ons aan die een kant uit die 
Bybel wat ons glo die Woord van God is waarin God uit genadige sondaarsliefde Hom aan ons openbaar. Aan die ander kant druk ons die inhoud van ons geloof uit in belydenis van geloof, die formulering waarvan die Belydenisskrifte is.

Nou gebruik die taal van die geloof dikwels dieselfde terme as wat die wetenskap gebruik. Voorbeelde is die terme bewys en kennis. Heb. 11:1 sê: „Die geloof dan is 'n vaste vertroue op die dinge wat ons hoop, 'n bewys van die dinge wat ons nie sien nie." Die Heidelbergse Kategismus Vr. 21 praat van die geloof as 'n „gewisse kennis." Ons moet egter besef dat die terme in weten. skaplike en in geloofsverband verskillende implikasies het: kennis is vir die wetenskap 'n menslike aangeleentheid, soos ons hierbo uiteengesit het; geloofskennis berus op die openbaring van God. Bewys vir die wetenskap beteken om 'n uitspraak terug te voer na sy gronde en hierdie gronde is altyd aan die een kant die feitelike gegewens aangaande die objek waaroor die uitspraak gemaak word en aan die ander kant die logiese funksies van die mens; bewys vir die geloof is geloofsekerheid wat ons uit die openbaring van God in Sy Woord en die getuienis van die Heilige Gees ontvang. Daarom is die aard van die wetenskaplike en die geloofsuitsprake ook totaal verskillend: waar die wetenskaplike uitspraak altyd hipoteties, relatief en voorlopig is omdat nuwe feitelike gegewens en rasionele insigte die wetenskaplike uitspraak kan verander, daar is die geloofsuitspraak finaal en absoluut - geen feitelike gegewens of rasionele insig kan ooit byvoorbeeld die geloofsuitspraak dat Jesus die Seun van God is, verander nie.

Geloof is die belangrikste komponent van wêreldbeskouing en lewensopvatting. Ons kan wêreldbeskouing en lewensopvatting nie van mekaar skei nie, maar wel onderskei. Wêreldbeskouing is ' $n$ teoretiese aangeleentheid waarin ons op redelike wyse rekenskap gee van die diepste wese van die syn, die ordelike samehang van die geheel van dinge en die plek van die mens binne hierdie geheel. Ons gee vir onsself op redelike wyse rekenskap, maar net so goed of nog meer moet die wêreldbeskouing beantwoord aan die eise van ons gemoed. Daarom sal ons in ons wêreldbeskouing rekening hou met die resultate van wetenskaplike navorsing, maar net soveel of nog meer met ons geloofsoortuiginge. Hiernaas is die lewensopvatting 'n praktiese aangeleentheid. Dit is ons diepste oortuiginge aangaande die behoorlike en onbehoorlike, die sin van menslike bestaan, die bestemming en taak van die enkeling so goed as die gemeenskap, die volk en die mensdom en so meer. Hier is van opperste belang ons geloof in God en ons geloofsgehoorsaamheid aan die geopen- 
baarde wil van God en dit is die laaste grond vir al die norme waarvolgens ons ons lewe lei. Ons geloof is dus van opperste belang vir en fundamentele komponent van ons wêreldbeskouing en lewensopvatting. Daarom praat ons met volle reg van ons Christelike wêreldbeskouing en lewensopvatting.

\section{CHRISTELIKE WETENSKAP:}

Hier moet ons nou oorgaan tot die bespreking van die vraag of dit moontlik is om van Christelike wetenskap te praat en indien wel, in welke sin dit moontlik is.

Deur die adjektief Christelik kwalifiseer ons wetenskap, met ander woorde ons sê dat Christelike wetenskap wetenskap is, maar dat dit anders is as byvoorbeeld Mohammedaanse of Buddhistiese of ateistiese of neutrale wetenskap. Ons kan dit verduidelik met 'n voorbeeld wat deur ons studente waardeer sal word: elkeen weet wat bedoel word met die woord aster. Maar nou kan ons allerlei adjektiewe byvoeg - mooi, lelik, vriendelik, ensovoorts. Met hierdie adjektiewe bedoel ons om naderby te spesifiseer en daarmee druk ons verskille uit - 'n mooi aster is anders as 'n lelike en so meer.

Ons staan dus voor die taak dat ons moet bepaal op welke wyse Christelike wetenskap anders is as bloot wetenskap. Om hierdie onderskeid te probeer vasstel, volg hier die punte van my uiteensetting van wetenskap.

1. Maak ons Christelike geloof 'n verskil aan die inhoudelike aspek van ons wetenskap? Hier gaan dit nou oor die feit dat wetenskap 'n corpus van kennis is, kennis van iets. Dit gaan met ander woorde oor die feitelike gegewenhede wat die inhoudelike deel van die wetenskap uitmaak. In hierdie verband is daar verskillende moontlikhede:

1.1. Die eerste moontlikheid is dat ons Christelike geloof die feitelike gegewens kan verander. Is die feite anders vir die gelowige as vir die ongelowige of vir die Christen anders as vir die Buddhis? Laat ons 'n paar voorbeelde neem uit veskillende tipes wetenskap:

Eestens: $2 \times 2=4$.

Tweedens: Water is die resultaat van die verbinding van waterstof en suurstof.

Derdens: Die oorsake van die Groot Trek was die onsimpatieke beleid van die Britse owerheid, die optrede van die negrofiliste en die rooftogte van die Bantoe.

Kan die feit dat iemand 'n Christen, 'n ateis of 'n Buddhis is enigiets aan hierdie feite verander? Klaarblyklik nie. Dit is objektiewe gegewens wat berus op ons logiese denke en/of waarneming. 
1.2. Die tweede moontlikheid is dat ons op grond van ons geloof feitelike gegewens beskikbaar het wat die nie-Christen nie het nie en ook beskikbaar kan hê nie. Byvoorbeeld: Die oorsake van die Groot Trek was die onsimpatieke beleid van die Britse owerheid, die optrede van die negrofiliste, die rooftogte van die Bantoe en die voorsienigheid van God wat die Voortrekkers bestem het as die mense wat die binneland vir die beskawing en die Christendom moes oopmaak. Hierdie laaste oorsaak, naamlik die voorsienigheid van God, kan alleen vir my bekend wees op grond van my geloof in God en Sy Woord. Nog 'n voorbeeld: 'n Plant is 'n lewende organisme wat uit dié en dié tipes selle opgebou is wat só en só funksioneer en wat deur God geskep is.

Nou moet ons goed besef wat hier gebeur: Ons neem 'n Bybelse uitspraak of 'n geloofswaarheid en plaas dit op dieselfde vlak as die empiriese gegewens, dit wil sê die gegewens wat deur die menslike vermoëns van waarneming en logiese denke verkry is. Ons doen dit omdat ons uitgaan van die vooropstelling dat die Bybel waar is, ja die hoogste en sekerste waarheid is en daarom moet meespreek in die wetenskap as die wetenskap ware uitsprake wil maak.

My beware hierteen is dat wetenskaplik aanvaarbare uitsprake verifieerbare uitsprake is. Met ander woorde elke uitspraak word getoets aan die feitelike gegewens en die menslike rede. As die Bybelse of geloofswaarheid as wetenskaplike gegewens moet geld, is dit onderhewig aan dieselfde toets. Daarmee degradeer ons nie net die Bybel en die geloof nie, maar ons maak van die Woord van God 'n soort wetenskaplike ensiklopedie. En omdat die Bybel die Woord van God is en geen wetenskaplike ensiklopedie is nie, kan die Bybelse en geloofswaarhede nie die toets van wetenskaplike verifikasie deurstaan nie. Daarom sal die Bybelse uitspraak elke keer in die wetenskaplike kritiek verwerp word, wat keer op keer in die verlede reeds gebeur het. Ons sien dit ook wanneer ons die Bybel gebruik as historiese dokument in ons studie van die antieke geskiedenis van die Nabye Ooste: as historiese dokument is die Bybel 'n waardevolle bron van gegewens, maar dit moet altyd oopstaan vir korreksie en aanvulling vanuit ander bronne.

Ek moet dus besluit dat die Christelike geloof ons geen feitelike gegewens lewer waaruit die wetenskap as wetenskap kan werk nie. Dat God in Sy genadige voorsienigheid die Voortrekkers gelei het en dat die plant 'n skepsel van God is, is waar, maar dit is geloofswaarhede, supra-teoretiese en suprawetenskaplike uitsprake wat nie met die mate van die wetenskap 
gemeet kan word nie, maar dan ook waarhede van 'n ander orde as die wetenskaplike waarheid wat nie op een vlak met die wetenskaplike waarheid gestel kan word nie.

Ek kan dit ook anders stel: die geloofswaarheid is die hoogste waarheid, die belangrikste waarheid - oneindig belangriker as die wetenskaplike waarheid. Maar die geloofswaarheid is nie ter sake vir die wetenskap nie.

Hierop kan baie kritiek uitgeoefen word.

Nogtans staan ek daarby: die geloofswaarheid is wetenskaplik nie ter sake nie. Maar om geen sweem van twyfel te laat oor my bedoeling nie, wil ek dit illustreer met 'n voorbeeld uit ons leefswêreld:

Ek en my vrou is besig om ons tuin her te beplan. In die noord-oostelike hoek moet ' $n$ boom kom, maar dit moet 'n boom met 'n breë, plat kruin wees. Ek kom van die klas af en kry my vrou in die tuin. Sy sê vir my: „Oom Koos sê ons moet 'n huilboon daar in die hoek plant. Hoe lyk 'n huilboon?" Ek antwoord haar: „Ons kan gerus 'n huilboon plant, want die liewe Heer het hom geskape." Sy antwoord my: „Man, dis nie wat ek wil weet nie. Ek wil weet hoe lyk 'n huilboon." - Beteken dit nou dat my vrou nie in God glo nie of nie glo dat God die boom geskep het nie? Glad en geheel en al nie. Dit beteken alleen dat die deur-God-geskape-wees van die boom in hierdie bepaalde verband nie ter sake is nie.

Deesdae sal die meeste voorstanders van die Christelike wetenskap egter vir my sê dat ek besig is om met windmeulens te veg. Hulle aanvaar nie dat die Bybel 'n wetenskaplike handboek is nie. Ek weet nie of almal so seker is op hierdie punt nie, maar al is dit so, dan is ek nogtans besig om die verskillende moontlikhede te oorweeg en uit te skakel.

1.3. Die derde moontlikheid is dat die Bybelse en geloofswaarhede nie as wetenskaplike gegewens gesien moet word nie, maar wel as die grond waarvandaan ons die feitelike gegewens van die wetenskap moet interpreteer.

Die argument lui ongeveer soos volg: feite is nooit losstaande, geîsoleerde, indiwiduele, in sigself geslote entiteite nie. Feite staan altyd binne 'n groter samehang en ons kan die betekenis van 'n feit alleen insien wanneer ons hom in sy samehang met die geheel sien. Om hierdie totale samehang in sy ware perspektief te sien, moet ons dit altyd van een of ander standpunt benader. Hierdie standpunt kan vir die Christen alleen die geloofstandpunt wees. Daarom sal die feitelike gegewens waarmee die Christen en die nie-Christen werk, miskien dieselfde wees, maar die Christen se wetenskap sal anders wees as die nie-Christen 
s'n, omdat die Christen die feitelike gegewens in 'n ander lig sien en vanuit ' $n$ ander standpunt interpreteer. Daarom het ons dan 'n Christelike en 'n nie-Christelike wetenskap.

Vir die grootste gedeelte stem ek in met hierdie gedagte, maar nie met die besluit wat daaruit afgelei word nie.

Dit is inderdaad so dat ' $n$ feit nie 'n geïsoleerde entiteit is nie. Dit is ook inderdaad so dat ons die samehang van feite vanuit 'n bepaalde standpunt interpreteer om dit verstaanbaar te maak.

Byvoorbeeld: die afsonderlike feite van die Groot Trek, byvoorbeeld die feit dat Piet Retief voor sy vertrek 'n manifes uitgereik het, moet almal in die groot geheel van die gebeure van die Groot Trek gesien word. Die Groot Trek moet weer gesien word binne die samehang van die geskiedenis van Suid-Afrika en selfs Europa wat daaraan voorafgaan en wat daarop volg. As ek die geskiedenis van die Groot Trek en wat daarmee saamhang, skrywe, kan ek dit geheel sien in die lig van die godsdienstige of politieke of ekonomiese of kulturele ensovoorts, betekenis daarvan; of ek kan dit interpreteer vanuit die standpunt van die vryheidsstryd of die nasionale bewuswording van die Afrikaner; of ek kan dit sien as deel van die rewolusionêre vloedgolf wat vanaf die Amerikaanse Onafhanklikheidsverklaring en die Franse Rewolusie gedurende die E 19 oor die Westerse Wêreld spoel.

Al hierdie samehange en interpretasies is wetenskaplik geregverdig omdat ons deur navorsing met die geykte metodes van die geskiedenis die samehang kan aantoon; asook dat die Groot Trek godsdienstige ens. betekenis gehad het, asook dat dit 'n verskynsel in die vryheidstryd van die Afrikaner is. En so meer. Dit beteken dat die eise van wetenskaplikheid, naamlik die erkenning van die feitelike gegewens en die geldigheid van die menslike rede, hier nagekom word. Dis nog steeds egte wetenskap.

Nou kan ons sê dat ons glo in die beskikking van God oor die lotgevalle van nasies. Hiervandaan af kan ons sê dat die beleid van die Britse owerheid, die Bantoerooftogte en die propaganda van die negrofiliste die roede was waarmee God Sy volk getugtig het, terwyl $\mathrm{Hy}$ in Sy genadige voorsienigheid besluit het dat daar leiers soos Piet Retief was. Wat ons daarmee uitspreek, is 'n geloofsbelydenis en nie wetenskap nie.

Maar selfs as ons nou die geskiedenis vanuit hierdie geloofsgesigspunt skrywe, kan ons geen ander verhaal vertel as die verhaal wat gebeur het nie. As ons al die klem op die godsdienstige aspek laat val, het ons nie 'n Christelike geskiedenis geskryf nie, maar 'n eensydige geskiedenis en kan ons van verdraaiing van 
die geskiedenis beskuldig word, net so goed as wat die Marxis van verdraaiing beskuldig word as hy die Groot Trek bloot as єkonomiese noodwendigheid interpreteer. En as ons die geskiedenis skryf in 'n terminologie en met sinswendinge wat keer op keer na vore bring dat God oor die lotgevalle van nasies beskik, het ons daarmee nog nie 'n ander geskiedenis geskryf nie, maar wel ons eie gesindheid getoon. Hierop kom ek later weer terug, maar wil dit tog met 'n voorbeeld verduidelik:

As ek die geskiedenis van dr. Verwoerd skryf, kan ek sê: Twee moordaanslae is op dr. Verwoerd gemaak. Albei is gedoen deur kranksinniges. Die eerste was gewapen met 'n pistool en alhoewel hy digby dr. Verwoerd gestaan het, het sy koeël nie dodelik getref nie, ens.

Ek kan ook skryf: Twee moordaanslae is op dr. Verwoerd gemaak, albei deur kranksinniges. Die eerste was gewapen met 'n pistool en alhoewel hy digby dr. Verwoerd gestaan het, het sy koeël deur die genadige bestiering van God nie dodelik getref nie. Ensovoorts.

In die tweede vertelling het ek presies dieselfde gesê as in die eerste. Die byvoeging "deur die genadige bestiering van God" sê niks van die gebeurtenisse nie, maar toon hul my gesindheid. Oor die betekenis van die gesindheid van die wetenskaplike praat ek later; hier wil ek alleen stel dat die gesindheid van die wetenskaplike nie wetenskaplik ter sake is nie.

Hier wil ek volstaan met die inhoudelike aspek van ons kennis. Ek gaan nou voort met:

2. Maak ons Christelike geloof 'n verskil aan die formele aspek van ons wetenskap? Hierby kan ons korter stilstaan, omdat die wesenlike reeds in verband met die inhoudelike aspek van ons wetenskap gesê is. Ek volg weer die punte wat genoem is by die bespreking van wetenskap:

2.1. Metode: Hieroor kan ek alleen sê dat ons geloof of ongeloof geen verskil aan die wetenskaplike metode kan maak nie. Christen en nie-Christen moet ewe goed die prosedure van feiteversameling, probleemformulering, hipotese forming en verifikasie volg. Net so goed moet albei gebruik maak van die spesifieke metodes en tegnieke wat in die verskillende wetenskappe gebruik word.

2.2. Fundering. Christen en nie-Christen fundeer immanent op dieselfde wyse. Die oordeel: „Honde is soogdiere” kan deur albei net op een manier fundeer word, naamlik in die waarreming.

Wanneer ons egter verder gaan na 'n finale of laaste fundering kom skerp verskille na vore. Die Christen sal byvoorbeeld praat van die skeppingsorde van God, terwyl die nie-Christen 
sy skouers agnosties sal optrek of van 'n natuurlike orde of wetmatigheid of so iets sal praat. Hier het ons egter die grense van die wetenskap oorskry; ons is besig met wêreldbeskouing waar die feitelike gegewens en die rede nie die laaste woord te spreke het nie, maar wel die geloofsbeslissing en die eise van die gemoed.

Een ding moet ons net opmerk en ek maak hierdie opmerking omdat dit pertinent van toepassing is op die voorstanders van die Christelike wetenskap: Wanneer ons die grense van die wetenskap oorskry, is dit van uiterste belang dat ons weet waarin ons ons begewe. Wat my persoonlik betref, is daar net een moontlikheid: As ek die strenge grense van die wetenskap verlaat, maak en die sprong na die persoonlike geloof in die God en Vader van Onse Here Jesus Christus. Daar is vir my net die twee sekerhede: die hipotetiese, relatiewe, menslike sekerheid van die wetenskap of die absolute sekerheid van die geloof. Om oor te gaan van die wetenskap na 'n metafisika, is hoogs twyfelagtig. Die pertinente voorbeeld hier is die filosofie van Herman Dooyeweerd. Ten spyte van al sy aansprake op Bybelse sanksie is: sy filosofie niks anders as 'n metafisiese sisteem nie en staan hy op gelyke voet met al die metafisikas vain die verlede en moet hy die vuursproef van die rasionele kritiek ondergaan - die kritiek waarvan die metafisika sedert Kant se dae nog nie weer herstel het nie.

2.3. Objektiwiteit. As daar 'n eis is wat tot die Christen meer behoort te spreek as enigiets anders, is dit die eis van objektiwiteit, omdat die Christen homself onder die gebod plaas: Jy mag geen valse getuienis teen jou naaste spreek nie. Om die wetenskap te gebruik as propaganda vir enige partikuliere standpunt van watter aard ook al, is 'n verloëning van die eis van objektiwiteit.

2.4. Verifieerbaarheid is ' $n$ eis wat vir die Christen ewe goed as die nie-Christen in sy wetenskaplike werk geld. Ons geloof kan hierin geen verskil maak nie.

2.5. Mededeelbaarheid in die gewone sin geld vir almal gelyklik en ons geloof maak hierin geen verskil nie. Daar is egter 'n sin waarin dit baie probleme oplewer: die voorstaanders van Christelike wetenskap praat graag oor die Wedergebore hart alleen die wedergebore hart is werklik in staat om waarheid te ken en daarom werklik tot wetenskap in staat. Dit volg logies uit hulle standpunt dat die feite in die lig van die Skrif gesien moet word. Maar as dit waar moes wees, beteken dit dat alleen die wedergebore Christen werklik wetenskaplik kan wees - wat geloën word deur die empiriese feit van talle groot wetenskaplikes 
wat nie Christene is nie. En as die wedergebore hart voorwaarde vir ware wetenskapsbeoefening is, is werklike kommunikasie tussen die Christelike wetenskaplike en die nie-Christen nie moontlik nie.

\section{E. GELOOF EN WETENSKAP:}

Tot sover het ek my bes gedoen om $u$ te oortuig dat dit sinloos is om van 'n Christelike, 'n ateïstiese, 'n Buddhistiese ens., wetenskap te praat. En ek moet byvoeg dat dit ewe goed sinloos is om van 'n neutrale wetenskap te praat, want die manier waarop die term neutraal hier by ons in Suid-Afrika gebruik word, beteken dit feitlik dieselfde as ateisties.

By wat ek reeds gesê het, wil ek nog voeg dat dit 'n empiriese feit is dat 'n Christelike wetenskap nie bestaan nie. Tot nog toe het so iets eenvoudig nie te voorskyn getree nie. Die voorstanders van Christelike wetenskap - filosowe soos Stoker, Dooyeweerd, Spier en andere sowel as vakwetenskaplikes soos Duyvené de Wit - skryf altyd oor Christelike wetenskap, oor geloof, die Bybel, wêreldbeskouing en lewensopvatting en hulle stel die eis dat daar so iets soos 'n Christelike wetenskap moet wees, maar 'n skrywer van Christelike geskiedenis of Christelike sosiologie of Christelike psigologie of Christelike fisika en so meer is my totaal onbekend. Die vakwetenskaplikes wat hulle by die gedagte van Christelike wetenskap skaar - en dit bedoel ek nie liefdeloos nie, maar as 'n oproep tot selfbesinning - kom nie verder as om hulle geloof in die voorwoord tot hulle boeke te bely nie. As die voorwoord afgehandel is, gaan hulle maar weer voort met doodgewone wetenskap wat deur ander mense ook beoefen word.

Beteken dit nou dat geloof en wetenskap twee aparte wêrelde is wat niks met mekaar te doen het nie? Nee, geensins nie. Oor hierdie verhouding wil ek nou praat, eers in negatiewe en dan in positiewe sin.

In die negatiewe sin wil ek stel dat elke en enige wetenskap wat sy grense oorskry en homself aanmatig om oor wêreldbeskouing en lewensopvatting, oor God, Bybel en geloofswaarhede uitsprake te maak, homself verloën en geen wetenskap meer is rie. Hy verabsoluteer homself, wat in botsing is met die wese van wetenskap. Ewe goed kan die geloof - ek moet liewer sê die teologie, wat self 'n mensgemaakte wetenskap is, maar vir homself somtyds nogal allerlei privileges kan opeis - sy grense oorskry en maak asof hy alwetend op wetenskaplike gebied is. Net so min as wat die wetenskaplike in die proefbuis kan aantoon dat daar nie 'n God is nie, kan die teologie op grond van die Bybel aantoon wat daar wel in die proefbuis gebeur. 
Hierdie grensoorskryding verloën die wese van die wetenskap en maak van die wetenskap wêreldbeskouing, lewensopvatting en kwasie-godsdiens. Wanneer ons hierdie grensoorskryding en verabsolutering van die wetenskap nog steeds wetenskap wil noem, moet ons inderdaad praat van 'n ateïstiese of Christelike of dergelike wetenskap. Maar ek dink dat dit onmoontlik is om van 'n Calvinistiese wetenskap te praat: die grensoorskryding wat by 'n proefbuis of 'n blaar kan begin en by God eindig, staan in die teken van die kontinuīteitsdenke. So 'n kontinuïteit is altyd vir die Calvinis onmoontlik omdat hy die sonde te radikaal ernstig opneem en die sonde altyd die diskontinuiteit tussen mens en God beteken.

In positiewe sin wil ek stel dat geloof vir die wetenskapsbeoefening van die allergrootste belang is. Ek kan dit na verskillende rigtings aantoon, maar ek wil net die volgende stel:

1. Ons Christelike geloof vereis van ons dat ons alles wat ons doen, ook ons wetenskapsbeoefening, tot eer van God maet doen. Dit mak van ons wetenskap nog geen Christelike wetenskap nie, maar dit bring mee dat ons voor God rekenskap moet kan gee van ons opregtheid, eerlikheid en waarheidsgetrouheid in ons wetenskapsbeoefening. En waarin ons deur ons kennis oor besondere vermoëns beskik, is ons as wetenskaplikes aan God en ons naaste verantwoording verskuldig oor wat ons met ons wetenskaplike kennis doen. Laat ek dit met 'n voorbeeld illustreer: die prosesse en tegnieke van atoomsplitsing bly dieselfde vir Christen en nie-Christen. Maar as daar van jou vereis word om deur die kennis wat jy het 'n atoombom te maak om ander mense uit te wis, moet jy aan God en jou naaste verantwoording doen vir wat jy met jou kennis doen.

2. Ons geloof leer ons dat daar net een ware God is. Daarom is enige vorm van verafgoding van die wetenskap onmoontlik en leer die wetenskaplike om sy wetenskap in ware perspektief te sien. Hy weet van sy menslike beperktheid en sonde; hy weet van die enigste verlossing wat daar vir die sondaar is en hy weet dat daar baie belangriker sake as die wetenskap is.

3. Wanneer die wetenskaplike ook dosent is leer sy Christelike geloof hom van sy enorme verantwoordelikheid teenoor die studente wat voor hom sit - nie net die verantwoordelikheid om die studente wetenskap te leer nie, maar ook om daardie selfde wetenskap in perspektief te sien.

4. Ons Christelike geloof bring ook mee dat ons die grense van die wetenskap erken. Elke versoeking om die wetenskap te verabsoluteer, te verhef tot kwasi-godsdiens word gesien vir wat dit is en in die kiem gesmoor. 


\section{TEN SLOTTE:}

Alles wat ons doen, moet ons doen tot eer van God - ook ons wetenskapsbeoefening. Dit bring vir my nie mee dat daar soiets soos Christelike wetenskap bestaan nie, maar dit beklemtoon die geweldige belangrikheid daarvan dat die wetenskaplike 'n gelowige Christen moet wees. Die saak is nie Christelik nie, kan dit nie wees nie, maar die mens kan en behoort dit te wees. Laat ek afsluit deur hierdie stelling te illustreer: Twee studente gaan met hulle negentien-voertsek Volkwagens (die gevaarlikste kombinasie wat daar is - 'n student met 'n Volkswagen) na die Intervarsity tussen Tukkies en Witsies kyk. Albei is uitgelate oor Tukkies se oorwinning. Student A klim in sy Volkswagen en ry op verantwoordelike wyse terug koshuis toe. Student B gaan vier die Intervarsity en ry in sy dronkenskap 'n mens dood. Die verskil tussen $A$ en $B$ lê nie in die Volkswagen nie, maar in die mense. B se Volkswagen is nie onchristelike omdat hy 'n mens doodgery het nie en A se Volkswagen Christelik omdat hy netjies huis toe gegaan het nie. Maar die mense, A en B, maak die hele verskil: albei moet dieselfde tegnieke gebruik om die Volkswagens te laat beweeg, maar dit is geweldig belangrik of die man agter die stuur 'n verantwoordelike Christenmens is of nie.

* Die inhoud van hierdie artikel is as referaat voorgedra voor 'n konferensie van die Departement Studenteskakeling van die Afrikaanse Studentebond, te Pretoria, 11 April 1970. 